\title{
Isolation, Renaturation and Partial Characterization of Recombinant Human Transferrin and its Half Molecules from Escherichia coli
}

\author{
PETER HOEFKENS, ${ }^{1}$ MAARTEN H. DE SMIT, ${ }^{1,2}$ \\ NEL M. H. DE JEU-JASPARS, ${ }^{1}$ MARJA I. E. HUIJSKES-HEINS,' \\ GERARD DE JONG, ${ }^{3}$ HENDRIK G. VAN EIJK ${ }^{1 *}$ \\ 'Department of Chemical Pathology, Erasmus University, Rotterdam, The Netherlands, \\ ${ }^{2}$ Department of Biochemistry, Leiden Institute of Chemistry, University of Leiden, Leiden, The \\ Netherlands and 'Department of Internal Medicine II, Academic Hospital Dijkzigt, Rotterdam, \\ The Netherlands
}

\begin{abstract}
Recombinant human transferrin as well as $\mathbf{N}$ - and $\mathrm{C}$-terminal half-transferrins, produced in Escherichia coli, are deposited in inclusion bodies by the bacteria. The isolation and purification of the recombinant proteins from these inclusion bodies are described here. The amino acid compositions and N-terminal sequences of the proteins were determined, and found to be in agreement with the known protein structure of human serum transferrin. Renaturatlon of the recombinant proteins is described, resulting in water-soluble iron-bindlng molecules. Iron binding wasconfirmed by ${ }^{59} \mathrm{Fe}$ labelling, absorption spectrophotometry and EPR spectrometry. Copyright (C) 1996 Elsevier Science Ltd
\end{abstract}

Keywords: Iron Recombinant transferrin Renaturation Inclusion bodies Escherichia coli

Int. J. Biochem. Cell Biol. (1996) 28, 975-982

\section{INTRODUCTION}

Transferrin is an $80 \mathrm{kDa}$ glycoprotein functioning as a ferric iron carrier in higher eukaryotes. Being one of the major serum proteins, it has been studied extensively since its first description (Schade and Caroline, 1946).

The amino acid sequence of human transferrin has been known for several years now (MacGillivray et al., 1982; Yang et al., 1984). The protein can be divided into two globular domains each containing one high affinity binding site for iron. These two globular

*To whom all correspondence should be addressed.

Abbreviations: DTT, dithiothreitol; EDTA, ethylenediaminetetra-acetic acid; IPTG, isopropyl- $\beta$-Dthiogalacto-pyranosidase; PAGE, polyacrylamide gel electrophoresis; thTf, recombinant human transferrin; $\operatorname{rhTf} / 2 \mathrm{C}$, recombinant human $\mathrm{C}$-terminal half-transferrin; rhTf/2N, recombinant human $\mathrm{N}$-terminal halftransferrin; hTf/2N, human N-terminal half-transferrin; hTf, human serum transferrin; GSH, glutathione, reduced form; GSSG, glutathione, oxidized form; NTA, nitrilotriacetic acid.

Received 1 November 1995; accepted 22 May 1996. domains show a high degree of internal homology.

The C-terminal domain (residues 337-679) carries two branched N-linked glycans. These two glycan chains are linked at the amide group of the asparagine residues at positions 413 and 611 through a $\mathrm{N}$-glycosidic linkage (Jamieson, 1964). No specific function has been ascribed to the carbohydrate moieties of transferrin so far. It has been reported that the glycan chains play no role in the binding of transferrin to its receptor (Mason et al., 1993), neither do they influence the secretion rate of transferrin by hepatoma cells (Bauer et al., 1985). Carbohydrate-deficient transferrin has been described in several fish species of the Cyprinidae family (Stratil et al., 1983, 1985).

During certain physiological and pathological conditions, such as pregnancy, rheumatoid arthritis, malignancies and alcohol abuse (van Eijk et al., 1987; de Jong et al., 1990, 1992; Léger et al., 1989; Yamashita et al., 1989; Stibler et al., 1978), characteristic changes in the glycan 
structures occur. The significance of this variation in microheterogeneity is not elucidated totally. In vitro experiments employing transferrins differing in their glycan composition have shown subtle differences in the processing of these transferrins by the organs most intimately involved in iron homeostasis in man. These results have been fitted in a model that explains the redistribution of iron between iron stores in iron deficiency, pregnancy and states of chronic inflammation (de Jong, 1993).

Studying the biochemical, structural and physiological properties of human transferrin lacking the carbohydrates could give more insight into the function of the glycans. Initial attempts to remove the glycans chemically or enzymatically turned out to be unsuccessful. Either transferrin was damaged irreversibly or the carbohydrates were only partially removed (de Jong et al., 1990, 1993). Another problem with enzymatic deglycosylation is that it can be applied only to small amounts of denatured transferrin, although successful use of enzymes under non-denaturing conditions has been reported (Padda and Schrijvers, 1990). The production of non-glycosylated transferrin in eukaryotic cells using site-directed mutagenesis has been described previously (Mason et al., 1993).

Large quantities of aglycotransferrin can be produced in a bacterial expression system (de Smit et al., 1995). Bacteria lack the rough endoplasmic reticulum and the Golgi system and, therefore, are not able to attach N-linked glycans to their products. For this reason, our group has directed its efforts at developing a system in which recombinant human transferrin DNA could be expressed in E. coli and recently has published the results (de Smit et al., 1995).

This bacterial expression system has been employed as our source for aglycotransferrin. Synthesized recombinant transferrin (rhTf) is deposited in a denatured state in large amorphous particles called inclusion bodies. This is true also for the $\mathrm{N}$ - and C-terminal half-transferrins (rhTf/2C and $\operatorname{rhTf} / 2 \mathrm{~N}$, respectively). Therefore, studying biochemical properties of these proteins requires previous renaturation.

Here, we report on the isolation, renaturation and partial characterization of $\operatorname{rhTf}, \operatorname{rhTf} / 2 \mathrm{~N}$ and $\mathrm{rhTf} / 2 \mathrm{C}$ from E. coli cultures expressing these proteins. Following purification, we determined the amino acid composition of the recombinant proteins in order to compare this with the theoretical composition that is known from the primary structure. In addition, the first 10-15 amino acids from the $\mathrm{N}$-terminal side of the three recombinant products were sequenced.

We renatured the recombinant transferrins into water soluble proteins and determined their iron-binding capacity.

\section{MATERIALS AND METHODS}

Production of $r h T f, r h T f / 2 N$ and $r h T f / 2 C$ in E. coli

Production of recombinant transferrin and the recombinant half-molecules was performed as described by de Smit et al. (1995).

\section{Purification of $r h T f, r h T f / 2 N$ and $r h T f / 2 C$}

To obtain cell lysates, the cultured bacteria were harvested using a MSE Coolspin centrifuge at $2600 \mathrm{~g}$ for $15 \mathrm{~min}$. The cells were resuspended in $10 \mathrm{ml} 50 \mathrm{mM}$ Tris $/ \mathrm{HCl}, 1 \mathrm{mM}$ EDTA, $250 \mathrm{mM} \mathrm{NaCl}, 5 \mathrm{mM}$ DTT, $\mathrm{pH} 8.0$ and disrupted by adding approximately $100000 \mathrm{U}$ lysozyme. After incubating for $30 \mathrm{~min}$ at room temperature, the sample was snap-frozen by submersing it in a mixture of solid CO, and ethanol. The thawed sample was sonicated. Approximately $300 \mathrm{U}$ DNase I was added and the sample was incubated for $45 \mathrm{~min}$ at room temperature.

The inclusion bodies were isolated from the cell lysate by centrifugation at $12000 \mathrm{~g}$ for $15 \mathrm{~min}$. The pellet was washed three times with $50 \mathrm{mM}$ Tris $/ \mathrm{HCl}, 1 \mathrm{mM}$ DTT, $\mathrm{pH} 8.0$ and dissolved in $10 \mathrm{ml} 8 \mathrm{M}$ urea, $1 \mathrm{mM}$ DTT, $40 \mathrm{mM}$ Tris/HCl, $10 \%$ glycerol (v/v), pH 7.6.

Preparative SDS electrophoresis was used to purify $\operatorname{rhTf}, \operatorname{rhTf} / 2 \mathrm{~N}$ and $\operatorname{rhTf} / 2 \mathrm{C}$. This was performed with a model 392 Bio-Rad Prep Cell. The $\operatorname{rhTf}, \operatorname{rhTf} / 2 \mathrm{~N}$ or $\mathrm{rhTf} / 2 \mathrm{C}$ solution $(600 \mu \mathrm{l})$ was mixed with an equal volume of $8 \%$ SDS $(\mathrm{w} / \mathrm{v}), 24 \%$ glycerol $(\mathrm{v} / \mathrm{v}), 50 \mathrm{mM}$ Tris $/ \mathrm{HCl}, 4 \%$ $\beta$-mercaptoethanol (v/v), $0.01 \%$ Serva blue $\mathrm{G}$ $(\mathrm{w} / \mathrm{v}), \mathrm{pH} 6.8$ and incubated for $30 \mathrm{~min}$ at $40^{\circ} \mathrm{C}$. This sample was applied to the polyacrylamide gel $(9 \% \mathrm{~T}, 3.3 \% \mathrm{C})$ of the Prep Cell. The purities of hTf and its half-molecules were examined on $9 \%$ SDS polyacrylamide gels after being concentrated with Centriflo CF 25 cones (Amicon). The samples were dialysed against $40 \mathrm{mM} \mathrm{NaHCO}$. The molecular cutoff was approximately $10 \mathrm{kDa}$. 
Amino acid analysis

The recombinant proteins were analysed using an Alpha Plus 4151 amino acid analyser (Pharmacia LKB Biochrom Ltd, Cambridge, U.K.). The proteins were hydrolysed by mixing $50 \mu \mathrm{l}(0.5-1.0 \mathrm{~g} / \mathrm{l})$ protein solution with $150 \mu \mathrm{l}$ $4 \mathrm{M}$ paratoluene sulphonic acid and $2 \%$ 3-(2-amino ethyl) indole $\mathrm{HCl}$ (van Eijk and van Noort, 1986). This mixture was incubated for $24 \mathrm{hr}$ at $110^{\circ} \mathrm{C}$. After hydrolysis, the mixture was titrated with $1 \mathrm{M} \mathrm{NaOH}$ to $\mathrm{pH} 2.0$ and $0.2 \mathrm{M}$ lithium citrate was added to a final volume of $2 \mathrm{ml}$. This mixture $(25 \mu \mathrm{l})$ was analysed. During the analysis, the eluent was mixed with a $0.2 \%(\mathrm{w} / \mathrm{v})$ ortho-phthal aldehyde (OPA) 'reagent in $1 \mathrm{M}$ borate. The signal was measured with a fluorometer F 1000 (Merck Hitachi, Amsterdam, The Netherlands). As a reference, we used a very pure human transferrin preparation (4-sialo-bibi-antennary transferrin of the genetic $\mathrm{C}$, type) isolated from serum obtained from adult healthy volunteers as described by van Noort et al. (1994).

For protein sequencing, a model 473A Protein Sequencer (Applied Biosystems) was used, performing Edman degradation and phenylthiohydantoin amino acid analysis.

\section{Renaturation of $r h T f, r h T f / 2 C$ and $r h T f / 2 N$}

Renaturation experiments were performed with inclusion body solution without further purification of the recombinant proteins. Prior to renaturation, the protein concentration of the inclusion body solution was determined according to the method of Bradford (Bradford, 1976).

Renaturation was performed by diluting the proteins in a renaturation buffer $(0.1 \mathrm{mM}$ Na-EDTA, $0.1 \mathrm{mM}$ Tris/HCl, $1.0 \mathrm{mM}$ GSH, $\mathrm{pH} 8.2,6^{\circ} \mathrm{C}$ ) to a concentration of $20 \mu \mathrm{g} / \mathrm{ml}$. The proteins were incubated for $15 \mathrm{~min}$. Subsequently, GSSG was added to a final concentration of $0.5 \mathrm{mM}$. This solution was incubated for another $22 \mathrm{hr}$ at $6^{\circ} \mathrm{C}$. Renaturation buffer was degassed thoroughly prior to use and renaturation was performed under an atmosphere of nitrogen. After incubation, the solution was concentrated and dialysed against $10 \mathrm{mM} \mathrm{NaHCO}$ using an Ultrasette with an omega $10 \mathrm{kDa}$ membrane (Filtron). Subsequently, the solution was filtered and concentrated further using an Amicon Stirred Cell with a PM 10 membrane and finally Centriflo cones, CF 25 (Amicon).

After concentration rhTf, rhTf/2C or $\mathrm{rhTf} /$
$2 \mathrm{~N}$ was saturated with iron using a $\mathrm{FeCl}_{3} / \mathrm{NTA}$ solution and separated from the other proteins using a Sepharose bound anti-transferrin column (van Eijk and van Noort, 1976).

To demonstrate the iron-binding capacity of the recombinant transferrins we saturated rhTf, rhTf $/ 2 \mathrm{C}$ and $\operatorname{rhTf} / 2 \mathrm{~N}$ with iron using a ${ }^{59} \mathrm{FeCl}_{3} / \mathrm{NTA}$ solution following standard procedures $\left({ }^{59} \mathrm{FeCl}_{3}\right.$; Amersham Life Science). The iron-saturated samples were loaded onto two $12.5 \%$ homogeneous polyacrylamide PhastGels (Pharmacia). One gel was used to illuminate an $\mathrm{X}$-ray film and the other gel was stained for proteins using Coomassie brilliant blue R-250. Also, we determined the molecular weight of the proteins in the different samples by running them on a $12.5 \%$ homogeneous SDS polyacrylamide gel.

\section{Spectrophotometry and EPR}

An absorption spectrum and an $\mathrm{A}_{280 / 470}$ ratio of the iron-saturated recombinant transferrins was determined using an Ultrospec III spectrophotometer and application software (Pharmacia, LKB).

The EPR spectra were determined using a Bruker EPR 200 D spectrometer as described by Pierik and Hagen (1990).

\section{RESULTS}

The $\operatorname{rhTf}, \operatorname{rhTf} / 2 \mathrm{C}$ and $\operatorname{rhTf} / 2 \mathrm{~N}$ samples purified from inclusion bodies by means of preparative SDS electrophoresis each showed one protein band on a 9\% SDS-PAGE (Fig. 1). As expected, rhTf migrated slightly faster then hTf. The lack of oligosaccharide chains reduces the Mw by approximately $4 \mathrm{kDa}$. The $\operatorname{rhTf} / 2 \mathrm{~N}$ and $\operatorname{rhTf} / 2 \mathrm{C}$ showed bands just above the $32.5 \mathrm{kDa}$ marker, which corresponds to the calculated $\mathrm{Mw}$ of respectively 37.3 and $38.3 \mathrm{kDa}$.

In Table 1 , the amino acid composition of $\operatorname{rhTf}, \operatorname{rhTf} / 2 \mathrm{~N}$ and $\operatorname{rhTf} / 2 \mathrm{C}$ is compared with hTf. The composition of the recombinant transferrins corresponds very well to the references. Most amino acids show less then 5\% deviation from the expected values. In Table 2, the first 10-15 amino acids sequenced from the $\mathrm{N}$-terminal side of the recombinant proteins are compared with the expected amino acids (Yang et al., 1984). These sequences match the references exactly, except for one $\mathrm{N}$-terminal extra methionine at each recombinant protein and a glutamic acid replacement by glutamine in 
rhTf/2C. The latter was introduced during construction of the expression plasmid and will be explained in the discussion.

An absorption spectrum of the iron-saturated recombinant transferrins was determined ranging from 280 to $600 \mathrm{~nm}$. Normal diferric human transferrin has an absorption maximum at $465 \mathrm{~nm}$. The recombinant transferrins showed spectra similar to those of diferric human transferrin with an absorption maximum at 462 , 459 and $464 \mathrm{~nm}$ for $\mathrm{rhTf}, \mathrm{rhTf} / 2 \mathrm{C}$ and $\mathrm{rhTf} / 2 \mathrm{~N}$, respectively. Normal diferric transferrin has an $\mathrm{A}_{280: 465}$ ratio equivalent to 21 ; this value also has been reported for iron-saturated $\mathrm{hTf} / 2 \mathrm{~N}$ (Funk et al., 1990). For $\operatorname{rhTf}, \operatorname{rhTf} / 2 \mathrm{C}$ and $\operatorname{rhTf} / 2 \mathrm{~N}$, we calculated values of 30,28 and 24 . Assuming these ratios can be converted into iron-saturation values, as can be done with normal transferrin, these figures correspond with 70 and $90 \%$ iron-saturation for $\operatorname{rhTf}$ and $\operatorname{rhTf} / 2 \mathrm{~N}$, respectively. Assuming the $\mathrm{A}_{280 ; 465}$ ratio for iron-saturated $\mathrm{hTf} / 2 \mathrm{C}$ is equal to that for $\mathrm{hTf}$ and $h \mathrm{Tf} / 2 \mathrm{~N}$, the calculated value for $\operatorname{rhTf} / 2 \mathrm{C}$ corresponds with $75 \%$ iron-saturation.

The EPR spectra of the recombinant transferrins are nearly identical with the spectrum of native transferrin (Fig. 4).

The renatured recombinant transferrins were saturated with ${ }^{59} \mathrm{Fe}$ using a ${ }^{59} \mathrm{FeCl}_{3} /$ NTA solution. This sample was run on a native polyacrylamide gel. The ${ }^{59} \mathrm{Fe}$ saturated recombinant proteins all show more than one band on the autoradiograph [Fig. 2(B)]. The difference in migration pattern between $\mathrm{rhTf} / 2 \mathrm{C}$ and $\mathrm{rhTf} /$ $2 \mathrm{~N}$ on the autoradiograph and the native polyacrylamide gel is remarkable. This difference is not seen on the SDS polyacrylamide gel (Fig. 3).

\section{DISCUSSION}

Here, we report on the purification and renaturation of human transferrin, C-terminal half-transferrin and N-terminal half-transferrin, produced in E. coli as described by de Smit et al. (1995). After purification, the amino acid compositions of the recombinant transferrin and the recombinant $\mathrm{N}$ - and C-terminal half-transferrins were determined. These compositions match very well with the ones to be expected, not only proving that the samples contain the proteins of interest to us, but also that they are very pure.

The N-terminal sequencing shows that the recombinant transferrins all have an extra methionine at the N-terminus (Table 2). The

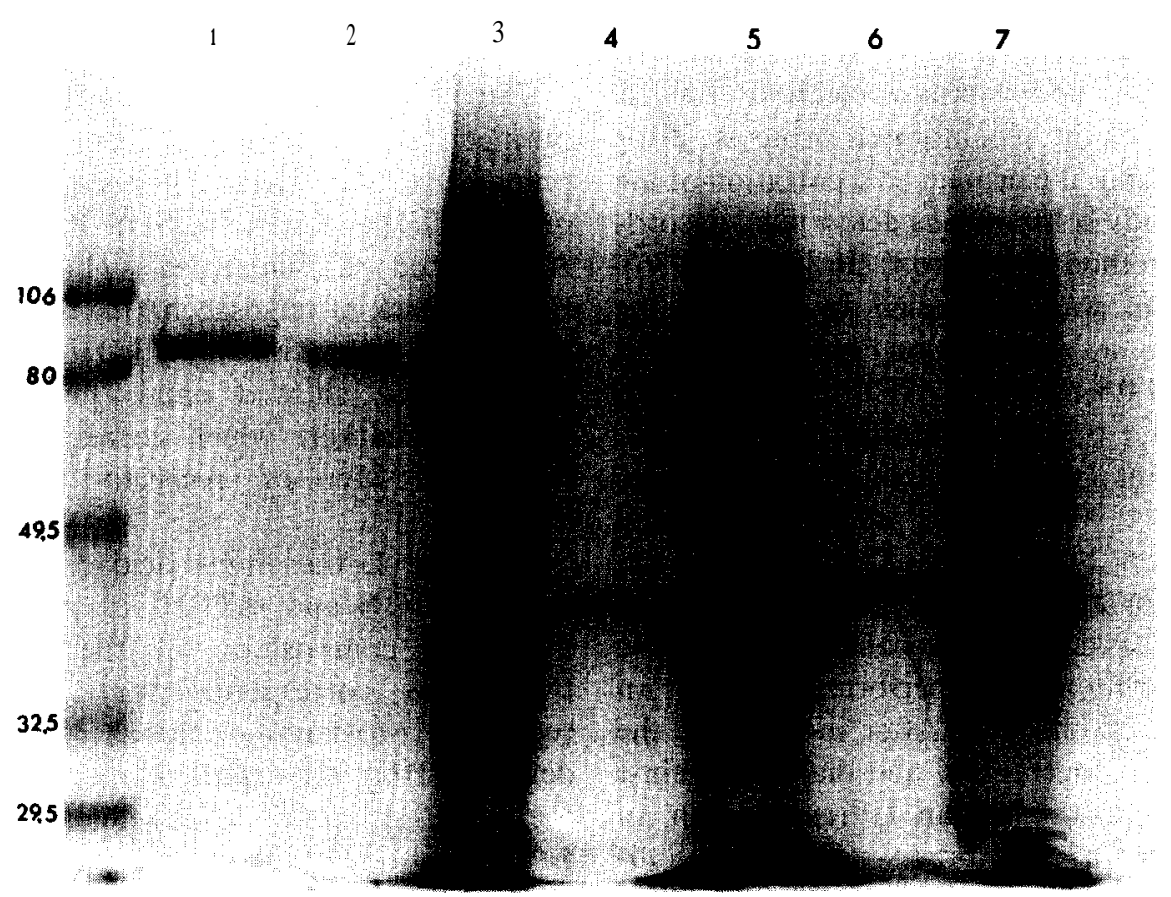

Fig. 1. The SDS-PAGE (9\%) showing the purified recombinant proteins and the solubilized inclusion bodies from which these proteins were isolated. Lane 1: hTf; lane 2: rhTf; lane 3: inclusion body solution containing rhTf; lane 4: $\operatorname{rhTf} / 2 \mathrm{~N}$; lane 5; inclusion body solution containing $\operatorname{rhTf} / 2 \mathrm{~N}$; lane $6: \operatorname{rhTf} / 2 \mathrm{C}$; lane 7: inclusion body solution containing $\mathrm{rhTf} / 2 \mathrm{C}$. Markers are indicated in $\mathrm{kDa}$. Staining was done with Coomassie brilliant blue G250. 
Table 1. Amino acid analysis of recombinant transferrins (mol amino acid/mol protein)*

\begin{tabular}{|c|c|c|c|c|c|c|}
\hline & $\begin{array}{l}\text { Recombinant } \\
\text { human } \\
\text { transferrin } \\
\text { (rhTf) }\end{array}$ & $\begin{array}{l}\text { Reference } \\
\text { values } \\
\text { serum } \\
\text { transferrin }\end{array}$ & $\begin{array}{r}\text { N-Terminal } \\
\text { half-transferrin } \\
(\mathrm{rhTf} / 2 \mathrm{~N})\end{array}$ & $\begin{array}{c}\text { Reference } \\
\text { values } \\
\text { N-terminal } \\
\text { part of serum } \\
\text { transferrin }\end{array}$ & $\begin{array}{l}\text { C-Terminal } \\
\text { half-transferrin } \\
\text { (rhTf/2C) }\end{array}$ & $\begin{array}{c}\text { Reference } \\
\text { values } \\
\text { C-terminal } \\
\text { part of serum } \\
\text { transferrin }\end{array}$ \\
\hline Lysine & 53.7 & 58 & 25.9 & 27 & 26.9 & 31 \\
\hline Histidine & 18.0 & 19 & 9.2 & 9 & 8.7 & 10 \\
\hline Arginine & 24.9 & 26 & 10.6 & 12 & 14.7 & 14 \\
\hline Aspartate $+\mathrm{NH}^{*}$ & 74.0 & 79 & 35.3 & 36 & 42.2 & 43 \\
\hline Threonine & 30.2 & 30 & 12.9 & 13 & 16.3 & 17 \\
\hline Serine & 40.4 & 41 & 20.2 & 21 & 20.6 & 20 \\
\hline Glutamate $+\mathrm{NH}, *$ & 57.8 & 59 & 28.5 & 29 & 32.4 & 30 \\
\hline Proline & N.D. $\dagger$ & 32 & N.D. & 20 & N.D. & 12 \\
\hline Glycine & 51.5 & 50 & 25.2 & 24 & 27.3 & 26 \\
\hline Alanine & 58.4 & 57 & 31.7 & 32 & 25.3 & 25 \\
\hline Cysteine & N.D. & 38 & N.D. & 16 & N.D. & 22 \\
\hline Valine & 44.7 & 45 & 22.7 & 22 & 22.3 & 23 \\
\hline Methionine & 9.4 & 9 & 5.8 & 5 & 5.3 & 4 \\
\hline Isoleucine & 14.6 & 15 & 7.8 & 8 & 7.6 & 7 \\
\hline Leucine & 55.2 & 59 & 30.7 & 29 & 29.5 & 30 \\
\hline Tyrosine & 26.0 & 26 & 15.2 & 14 & 12.0 & 12 \\
\hline Phenylalanine & 25.8 & 28 & 15.4 & 16 & 13.1 & 12 \\
\hline Tryptophan & 7.5 & 8 & 2.9 & 3 & 4.2 & 5 \\
\hline Total & & 679 & & 336 & & 343 \\
\hline $\begin{array}{l}\text { Total minus Cys } \\
\text { and minus Pro }\end{array}$ & 592.1 & 609 & 300 & 300 & 308.4 & 309 \\
\hline $\begin{array}{ll}\text { Deviation } & \text { from } \\
\text { predicted } & \text { values: }\end{array}$ & $3.6 \%$ & & $3.3 \%$ & & $5.5 \%$ & \\
\hline
\end{tabular}

*Sums of asparagine and aspartate and sums of glutamine and glutamate are given because of interconversion of these amino acids in the hydrolysis procedure.

tThe colour reactant used in the analysis procedure yields low absorbance products for proline and cysteine, which therefore are not determined (N.D.).

†The deviation represents the cumulated difference between determined numbers of separate amino acids in the transferrin species compared to the reference values derived from figures based on the transferrin characterization by Yang et al. (1984).

difference in the amino acid sequence of $\mathrm{rhTf} / 2 \mathrm{C}$ (amino acid 338) is due to the introduction of a KpnI-site in the transferrin cDNA (de Smit et al., 1995). Apart from this, the amino acid sequences of the recombinant transferrins match the expected sequences exactly (Yang et al., 1984).
For our first renaturation experiments, we used SDS/urea-denatured reduced hTf. All attempts to renature transferrin after such treatment failed. Although total removal of SDS from proteins has been reported (Kapp and Vinogradov, 1978; Hager and Burgess, 1980; Suzuki and Terada, 1988), we were not

Table 2. Amino acid sequence of the recombinant transferrins, sequenced from the $\mathrm{N}$-terminus, compared with the expected sequence according to Yang et al. (1984)

\begin{tabular}{|c|c|c|c|c|}
\hline Serum $\mathrm{Tf}$ & $\operatorname{rhTf}$ & $\operatorname{rhTf} / 2 \mathrm{~N}$ & Serum Tf & $\operatorname{rhTf} / 2 \mathrm{C}$ \\
\hline & Met & Met & & Met \\
\hline $01 \mathrm{Val}$ & Val & Val & 337 Asp & Asp \\
\hline 02 Pro & Pro & Pro & 338 Glu & Gln \\
\hline 03 Asp & Asp & Asp & 339 суs & Cys \\
\hline 04 Lys & Lys & Lys & 340 Lys & Lys \\
\hline $05 \mathrm{Thr}$ & Thr & Thr & 341 Pro & Pro \\
\hline $06 \mathrm{Val}$ & Val & Val & 342 Val & Val \\
\hline 07 Arg & Arg & Arg & 343 Lys & Lys \\
\hline 08 Trp & Trp & Trp & 344 Trp & Trp \\
\hline 09 cys & Cys & Cys & 345 cys & Cys \\
\hline 10 Ala & Ala & Ala & 346 Ala & Ala \\
\hline $11 \mathrm{Val}$ & Val & Val & 347 Leu & Leu \\
\hline $12 \mathrm{Ser}$ & Ser & Ser & & \\
\hline 13 Glu & Glu & Glu & & \\
\hline $14 \mathrm{His}$ & His & His & & \\
\hline
\end{tabular}


Fig. 2. (Left panel) Native PAGE (12.5\%) showing the renatured recombinant proteins. Lane 1: hTf (Behringwerke); lane 2: rhTf; lane 3: rhTf/2C; lane 4: rhTf/2N. (Right panel) Autoradiograph of a comparable gel to that shown in the left panel, except the recombinant proteins were saturated with ${ }^{59} \mathrm{Fe}$.

able to remove this detergent from denatured transferrin without complete precipitation of the protein of interest. Hence, renaturation experiments were performed with inclusion body solution following a procedure derived from Hirose (Hirose et al., 1989; Hirose and Yamashita, 1991) and adapted to our experimental system; i.e. prior isolation of the recombinant proteins by means of preparative SDS electrophoresis was abandoned.

After renaturation and purification, the recombinant transferrins all show a few bands on a native polyacrylamide gel [Fig. 2(A)]. This phenomenon is not caused by differences in molecular weight, because the same samples all show one single band on an SDS gel (Fig. 3),

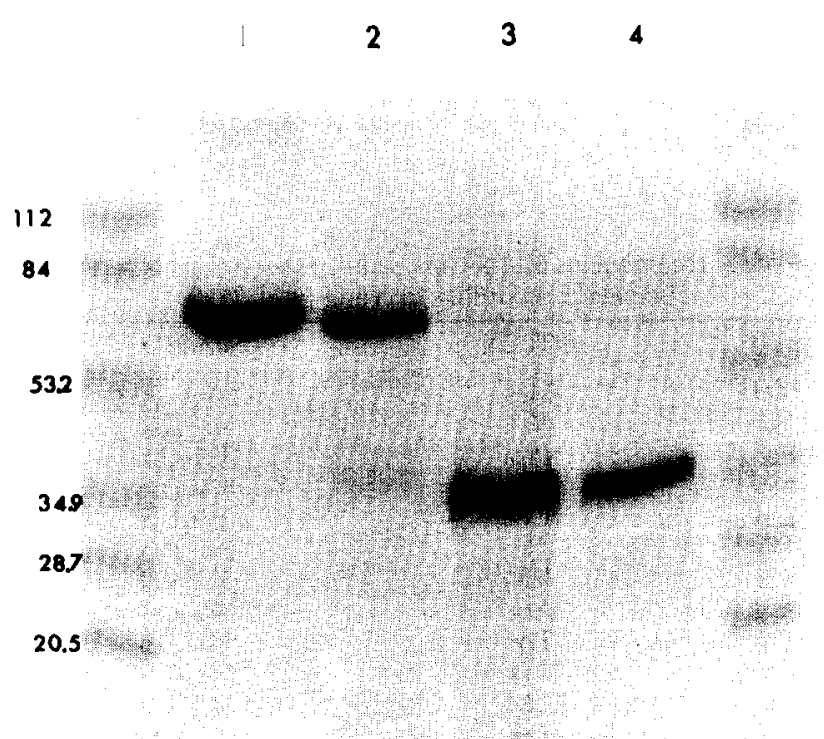

Fig. 3. The SDS-PAGE $(12.5 \%)$ showing the renatured recombinant proteins. Lane 1: hTf (Behringwerke); lane 2: rhTf; lane 3: rhTf/2C; lane 4: rhTf/2N. Markers are indicated in kDa. Staining was done with Coomassie brilliant blue R250. 


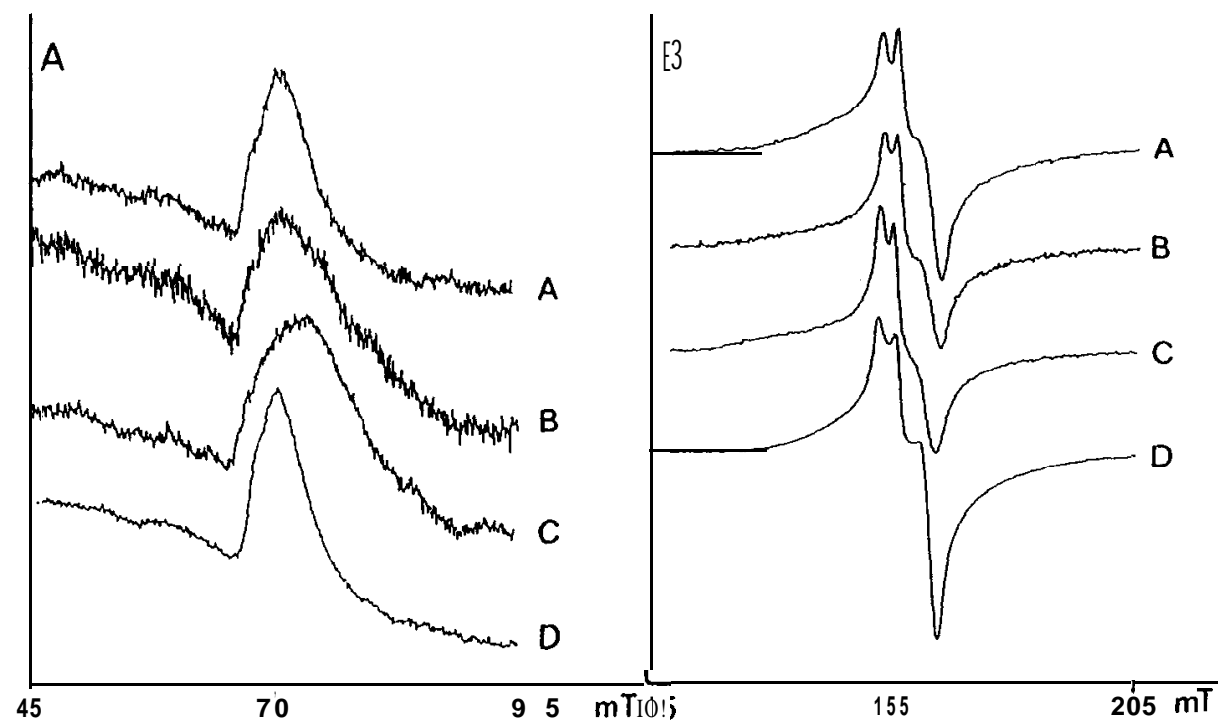

Fig. 4. Comparison of the EPR spectra of hTf and the recombinant transferrins. A: hTf; B: rhTf; C: $\operatorname{rhTf} / 2 \mathrm{~N} ; \mathrm{D}: \operatorname{rhTf} / 2 \mathrm{C}$. EPR conditions for (A): microwave frequency, $9315 \mathrm{MHz}$; microwave power, $80 \mathrm{~mW}$; modulation amplitude, $0.8 \mathrm{mT}$; temperature, $9 \mathrm{~K}$. EPR conditions for (B): microwave frequency, $9315 \mathrm{MHz}$; microwave power, $0.8 \mathrm{~mW}$; modulation amplitude, $0.5 \mathrm{mT}$; temperature, $9 \mathrm{~K}$.

except for a weak second band in lane 2, corresponding with half-transferrin. This could be explained easily as a result of proteolytic activity in $E$. coli during growth or during the inclusion body isolation procedure.

An explanation for the several minor bands on the native gel could be that different mobilities represent different conformations of the protein, e.g. due to variations in disulphide bond formation. These conformational differences could affect the iron-binding sites, resulting in a decreased iron saturation. One of the major $\mathrm{rhTf} / 2 \mathrm{C}$ bands migrated approximately as far as the rhTf bands on the native $12.5 \%$ homogeneous polyacylamide gel [Fig. 2(A)] but, on a gradient polyacrylamide gel (PhastGel 8-25\%), this band shifted more towards the rhTf $/ 2 \mathrm{~N}$ bands, indicating that this band is not a dimer. Dimerization as a result of intermolecular disulphide bridge formation was excluded for all the recombinant transferrins, since none of the recombinant proteins showed any extra bands on a $12.5 \%$ homogeneous polyacrylamide SDS gel run under non-reducing conditions compared with an SDS gel run under reducing conditions (not shown). In both cases, the recombinant proteins were saturated with SDS by incubating them in sample buffer (with or without $\beta$-mercaptoethanol) at $40^{\circ} \mathrm{C}$ for $30 \mathrm{~min}$.

The recombinant transferrins all are capable of binding iron as shown on the autoradiograph [Fig. 2(B)]. This is indicated also by the similarity of the recombinant transferrin adsorption spectra with the spectrum of iron-satu- rated hTf. All the spectra have an adsorption maximum near $465 \mathrm{~nm}$. The EPR spectra of the recombinant proteins are nearly identical with the EPR spectrum of hTf. Thus, the iron atoms in the recombinant proteins and in the native transferrin are bound in a similar way. This strongly suggests that the iron-binding sites of the recombinant transferrins are intact.

The minor differences seen in the EPR spectra are possibly a result of differences between the transferrins, e.g. lack of oligosaccharides.

As described by de Smit et al. (1995), production of recombinant transferrin in $E$. coli amounts to $60 \mathrm{mg} / \mathrm{l}$. The renaturation procedure has a final yield of approximately $5 \%$.

Several authors have reported the production of recombinant transferrin in E. coli (Hershberger et al., 1991; Steinlein and Ikeda, 1993). Hershberger et al. (1991) also reported on renaturation of recombinant transferrin, although no data were shown. Our work describes the production as well as the isolation, partial characterization, renaturation and ironbinding capacity of recombinant transferrin and both its half molecules. Renaturation of the recombinant transferrins results in watersoluble, iron-binding molecules.

Acknowledgements-We thank Professor W. R. Hagen of the Department of Biochemistry, Agricultural University, Wageningen, for performing the EPR measurements. We thank Marjan Kroos of the Institute of Clinical Genetics, Erasmus University, Rotterdam, for performing the amino acid sequencing and Willem van Noort for determining the amino acid composition of the recombinant proteins. 


\section{REFERENCES}

Bauer H. C., Parent J. B. and Olden K. (1985) Role of carbohydrate in glycoprotein secretion by human hepatoma cells. Biochem. Biophys. Res. Commun. 128, 368-375.

Bradford M. M. (1976) A rapid and sensitive method for the quantitation of microgram quantities of protein utilizing the principle of protein-dye binding. Anal. Biochem. 72, $248-254$

de Jong G., van Dijk J. P. and van Eijk H. G. (1990) The biology of transferrin. Clin. Chim. Acta 190, 1-46.

de Jong G., van Noort W. L., Feelders R. A., de Jeu-Jaspars C. M. H. and van Eijk H. G. (1992) Adaptation of transferrin protein and glycan synthesis. Clin. Chim. Acta 212, 2745.

de Jong G. (1993) The physiological significance of transferrin microheterogeneity. An interpretation of the role of N-linked glycans in transferrin microheterogeneity. Thesis, Erasmus University, Rotterdam, The Netherlands

de Smit M. H., Hoefkens P., de Jong G., van Duin J., van Knippenberg P. H. and van Eijk H. G. (1995) Optimized bacterial production of nonglycosylated human transferrin and its half-molecules. Int. J. Biochem. Cell Biol. 27, $839-850$

Funk W. D., MacGillivray R. T. A., Mason A. B., Brown S. A. and Woodworth R. C. (1990) Expression of the amino-terminal half-molecule of human serum transferrin in cultured cells and characterization of the recombinant protein. Biochemistry 29, 1654-1660.

Hager D. A. and Burgess R. R. (1980) Elution of proteins from sodium dodecyl sulfate, and renaturation of enzymatic activity: results with sigma subunit of Escherichia coli RNA polymerase, wheat germ DNA topoisomerase, and other enzymes. Anal. Biochem. 109, 7686

Hershberger C. L., Larson J. L., Arnold B., Rosteck Jr P. R., Williams P., DeHoff B., Dunn P., O'Neal K. L., Riemen M. W., Tice P. A., Crofts R. and Ivancic J. (1991) A cloned gene for human transferrin. Ann. NY Acad. Sci. $646,140-154$.

Hirose M., Akuta T. and Takahashi N. (1989) Renaturation of ovotransferrin under two-step conditions allowing primary folding of the fully reduced form and the subsequent regeneration of the intramolecular disulfides. J. Biol. Chem. 264, 16867-16872.

Hirose M. and Yamashita H. (1991) Partially folded state of the disulfide-reduced N-terminal half-molecule of ovotransferrin as a renaturation intermediate. J. Biol. Chem. 266, 1463-1468.

Jamieson G. A. (1964) The isolation of sialoglycopeptides from human transferrin. Biochem. Biophys. Res. Commun. 17, 775-780.

Kapp 0. H. and Vinogradov S. N. (1978) Removal of sodium dodecyl sulfate from proteins. Anal. Biochem. 91, 230-235.

Léger D., Campion B., Decottignies J.-P., Montreuil J. and Spik G. (1989) Physiological significance of the marked increased branching of the glycans of human serotransferrin during pregnancy. Biochem. J. 257, 231-238.

MacGillivray R. T. A., Mendez E., Sinha S. K., Sutton M. R., Lineback-Zins J. and Brew K. (1982) The complete amino acid sequence of human serum transferrin. Biochemistry 79, 2504-2508.

Mason A. B., Miller K. M., Funk W. D., Banfield D. K., Savage K. J., Oliver R. W. A., Green B. N., MacGillivray R. T. A. and Woodworth R. C. (1993) Expression of glycosylated and nonglycosylated human transferrin in mammalian cells. Characterization of the recombinant proteins with comparison to three commercially available transferrins. Biochemistry 32, 5472-5479.

Padda J. S. and Schrijvers A. B. (1990) N-linked oligosaccharides of human transferrin are not required for binding to bacterial transferrin receptors. Infect. Immunol. 58, 2972-2976.

Pierik A. J. and Hagen W. R. (1990) $\mathrm{S}=9 / 2$ EPR signals are evidence against coupling between the siroheme and the $\mathrm{Fe} / \mathrm{S}$ cluster prosthetic groups in Desulfovibrio vulgaris (Hildenborough) dissimilatory sulfite reductase. Eur. J. Biochem. 195, 505-516.

Schade A. L. and Caroline L. (1946) An iron binding component in human blood plasma. Science 104, 340-341.

Steinlein L. M. and Ikeda R. A. (1993) Production of $\mathrm{N}$-terminal and C-terminal human serum transferrin in Escherichia coli. Enz. Microbiol. Technol. 15, 193-199.

Stibler H., Allgulander C., Borg S. and Kjellin K. G. (1978) Abnormal microheterogeneity of transferrin in serum and cerebrospinal fluid in alcoholism. Acta Med. Scand. 204 49-56.

Strati1 A., Bobák P., Valenta M. and Tomasek V. (1983) Partial characterization of transferrins of some species of the family Cyprinidae. Comp. Biochem. Physiol. 74B, 603-610.

Stratil A., Tomásek V., Clamps J. R. and Williams J. (1985) Partial characterization of transferrins of catfish (Silurus glanis L.) and pike (Esox lucius L.). Comp. Biochem. Physiol. 80B, 909-9 11.

Suzuki H. and Terada T. (1988) Removal of dodecyl sulfate from protein solution. Anal. Biochem. 172, 259-263.

van Eijk H. G. and van Noort W. L. (1976) Isolation of rat transferrin using $\mathrm{CNBr}$-activated sepharose 4 B. J. Clin. Chem. Biochem. 14, 475-478.

van Eijk H. G. and van Noort W. L. (1986) The reliability of the use of para toluene sulfonic acid for simultaneous hydrolysis and quantitation of both $\mathrm{N}$-acetyl-glucosamine and amino acids in human transferrins. C/in. Chim. Acta 157, 305.3 10 .

van Eijk H. G., van Noort W. L., de Jong G. and Koster J. F. (1987) Human serum sialo transferrins in diseases. Clin. Chim. Acra 165, 141-145.

van Noort W. L., de Jong G. and van Eijk H. G. (1994) Purification of isotransferrins by concanavalin a sepharose chromatography and preparative isoelectric focusing. Eur. J. C/in. Chem. Clin. Biochem. 32, 885-892.

Yamashita K., Koide N., Endo T., Iwaki Y. and Kobata A. (1989) Altered glycosylation of serum transferrin of patients with hepatocellular carcinoma. J, Biol. Chem. 264, 2415-2423.

Yang F., Lum J. B., McGill J. R., Moore C. M., Naylor S. L., van Bragt P. H., Baldwin W. D. and Bowman B. H. (1984) Human transferrin: cDNA characterization and chromosomal localization. Proc. Natl Acad. Sci. USA 81, 2752-2756. 